\title{
Penerapan Model Pendidikan Gerak untuk Meningkatkan Keterampilan Bermain Kasti pada Siswa Sekolah Dasar
}

Friskie Siti Al'Fiyah Mawar Dani

Sekolah Dasar Negeri Jati 1 Garut, Jawa Barat

\section{Info Artikel}

SejarahArtikel:

Diterima September 2018

Disetujui April 2019

Dipublikasikan Mei 2019

Keywords:

Fielding Games, Keterampilan Bermain Kasti, Model Pendidikan Gerak

\begin{abstract}
Abstrak
Tujuan dari penelitian ini adalah untuk mengetahui pengaruh dari penerapan model pendidikan gerak berbasis permainan terhadap keterampilan bermain kasti siswa SD. Metode yang digunakan adalah Penelitian Tindakan Kelas (PTK) dengan 2 siklus, yang terdiri dari masing-masing 2 pertemuan. Penelitian dilakukan di SDN 044 Cicadas Awigombong, Kota Bandung, dengan sampel kelas IV yang berjumlah 34 (17 laki-laki dan 17 perempuan). Instrumen yang digunakan adalah Games Performance Asessment Instrument. Berdasarkan data hasil penelitian, dapat disimpulkan bahwa pemahaman dan performa bermain kasti siswa meningkat.
\end{abstract}

\begin{abstract}
The purpose of this study was to determine the effect of the application of the game-format of movement education model toward kasti playing skills on elementary school students'. It's used classroom action research with two cycles and each of which consist of two action. Participants of this study were 34 elementary school student in Bandung, consist of 17 males and 17 females. The instrument used Games Performance Assessment Instrument. The results are the average scores obtained by students. Based on the data, it can be concluded that children's understanding and games performance improved.
\end{abstract}




\section{PENDAHULUAN}

Pendidikan jasmani merupakan bagian integral dari proses pendidikan umum, sehingga dipandang beralasan bahwa pelajaran pendidikan jasmani merupakan pelajaran yang penting dalam proses pendidikan anak. Oleh karenanya, guru pendidikan jasmani diharapkan mampu memberikan pengajaran yang kreatif, inovatif, menyenangkan, sehingga siswa mampu mengikuti pembelajaran. Aktivitas fisik regular akan meningkatkan fungsi kognisi dan meningkatkan respon otak secara substansif dan bertanggung jawab memelihara kesehatan neuron (Scheuer, L. J., \& Mitchell, D., 2003). Karenanya tidak dapat dipungkiri bahwa tugas utama guru penjasorkes di sekolah dasar adalah mengemas pembelajaran semenarik mungkin dengan menyesuaikan karakteristik dan perkembangan anak-anak sekolah dasar (Nuryadi, dkk. 2018).

Pendidikan jasmani pada anak-anak Sekolah Dasar diharapkan bisa meningkatkan kebugaran peserta didik melalui aktivitas permainan salah satunya adalah permainan bola kasti. Olahraga ini termasuk jenis permainan dengan menggunakan bola kecil atau disebut dengan permainan bola kecil (Gustafianuus, 2013). Permainan kasti merupakan permainan fielding games. Bisa menjadi dasar untuk ke tahap olahraga prestasi seperti softball dan baseball. Keterampilan dasar yang diperlukan dalam permainan fielding games, diantaranya berlari, melempar bola, menangkap bola, memukul bola. Bahkan sangat dibutuhkan kerjasama, dan kekompakan antar kelompok bermain, ini yang membuat permainan fielding games terutama permainan kasti sangat menyenangkan dimainkan oleh ank-anak. Untuk dapat melakukan permainan kasti dengan baik maka setiap pemain harus memiliki keterampilan teknik dasar bermain kasti dengan baik.

Pendekatan teknis menekankan siswa untuk menguasai teknik-teknik dasar olahraga dari olahraga yang dipelajari. Menurut para ahli, pendekatan teknis ini memiliki kelemahan di antaranya adalah: 1) membutuhkan waktu yang tidak sebentar, 2) membutuhkan tahapan hirarkis dari mulai yang termudah sampai yang tersulit, 3) membutuhkan kesabaran dari anak karena pendekatan ini banyak mengandung proses drill yang dilakukan berulang-ulang. Dalam hal ini, guru pun dapat berganti-ganti teknik meskipun dalam koridor metode yang sama. Sebab pembelajaran teknis lebih cocok digunakan untuk strategi latihan atlit. Pendekatan teknis merupakan pendekatan yang menitik beratkan pada pembelajaran teknik dasar permainan. Maka dapat dibandingkan antara pendekatan teknis dan model pendidikan gerak lebih efektif model pendidikan gerak sebab dalam pendidikan teknis anak hanya mengenal teknik-teik dasar sajah tidka seperti model pendidikan gerak anak dibebaskan untuk melakukan gerak sehingga ana dapat melakukan berbagai aktivitas gerak.

Salah satu solusi yang dapat digunakan untuk menyelesaikan masalah siswa yang kurang antusias dalam pembelajaran penjas adalah dengan memilih salah satu model pembelajaran yang tepat sebagai salah satu upaya dalam meningkatkan keterampilan berpikir kritis siswa (Sapitri, Kurniawan, \& Sulistri, 2016). Dalam konstelasi model-model pembelajaran yang sudah dikembangkan dalam penjas di SD, terdapat model pembelajaran yang efektif untuk pembelajaran penjas di SD, yaitu model pen- 
didikan gerak. Dengan model pendidikan gerak, kemampuan anak dalam melakukan gerak dasar fundamental akan berkembang, yang secara tidak langsung anak melakukan berbagai gerakan yang sifatnya fungsional, termasuk yang tidak dikenalnya, tetapi merupakan dasar dari keterampilan yang lebih tinggi (Mahendra, 2017).

Model pendidikan gerak dianggap sebagai sebuah paradigma baru yang mengajarkan kepada setiap individu untuk berpartisipasi dalam budaya gerak. Ia mengajarkan konsep dan komponen gerak dasar, yang di dalamnya mengandung komponen kognitif yang kuat. Dalam penerapannya, tantangan dan permasalahan gerak disajikan dalam bentuk-bentuk tugas gerak yang selalu memperhitungkan keterlibatan faktor kognitif, afektif, sosial, serta teknik -teknik atau keterampilan untuk dipecahkan oleh siswa dan penyajian bentuk masalah gerak berupa permainan (Mahendra, 2017).

Pada pembelajaran gerak terdapat situasi yang menstimulasi proses pembelajaran pada aspek kognitif siswa (Stephani, 2017). Melalui pengalaman gerak, siswa bisa mendapatkan perasaan-perasaan diakui, memiliki dan keberhasilan. Di samping itu sifat-sifat sosial seperti kejujuran, sportivitas, dan dapat dipercaya, yang mendukung kepribadian yang diinginkan secara sosial dapat dikembangkan (Rustiana, 2013). Pada penelitian ini, peneliti akan menerapkan model pendidikan gerak pada pembelajaran kasti.

\section{METODE PENELITIAN}

Metode yang digunakan dalam penelitian ini adalah metode kuantitatif; dan sesuai dengan kondisinya maka jenis penelitian yang penulis lakukan adalah jenis penelitian tindakan kelas (PTK). PTK mempunyai manfaat yang cukup besar, baik bagi guru yaitu dapat memperbaiki kualitas pembelajaran yang ada di sekolah.

Penelitian ini dilakukan dengan melibatkan 2 siklus di mana setiap siklusnya terdiri dari 2 tindakan, sehingga semuanya berjumlah 4 pertemuan. Dalam penelitian ini yang menjadi populasinya adalah siswa- siswi kelas IV sebab siswa kelas IV tidak megenal pembelajaran kasti karena belum pernah diberikan pembelajaran kasti oleh guru pendidikan jasmani di SDN 044 Cicadas Awigombong. Permainan kasti juga mampu meningkatkan perkembangan dari keterampilan gerak dasar fundamental anak. dan yang menjadi sampelnya adalah kelas IV yang berjumlah 34 siswa, terdiri dari 17 siswa lakilaki dan 17 siswa perempuan.

Instrumen yang digunakan untuk mengukur keterampilan bermain dalam penelitian ini GPAI (Games Performance Assesment Instrument), yaitu instrumen yang digunakan untuk menilai kemampuan dan keterampilan siswa dalam melakukan permainan. Menurut (Oslin, Mitchell, \& Griffin, 1998), GPAI telah berkembang sebagai suatu alat kelengkapan penilaian untuk guru gunakan dalam berbagai variasi permainan.

\section{HASIL PENELITIAN}

Pada Penelitian dilakukan untuk mengetahui bagaimana hasil dari setiap tindakan yang dilakukan apakah keterampilan bermain kasti dan gerak lokomotor serta manipulatifnya meningkat atau tidak. Dari hasil observasi awal yang telah diteliti oleh peneliti tersaji di dalam gambar 1 


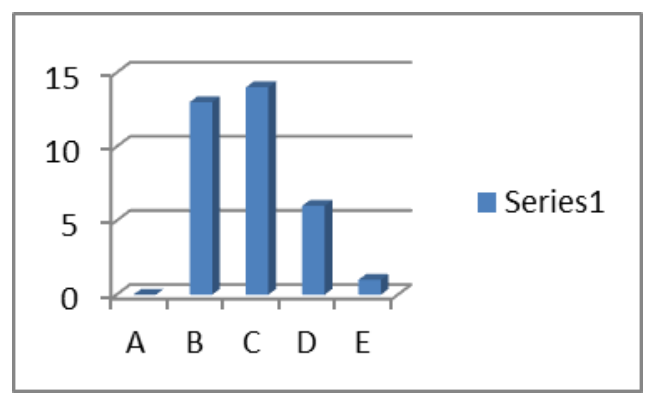

Gambar 1. Hasil Observasi Awal

Berdasarkan hasil observasi awal pada (grafik 4.1) peneliti menemukan bahwa kemampuan siswa dalam melaksanakan atau menguasai keterampilan bermain kasti masih sangat rendah, siswa yang mendapatkan nilai $\mathrm{A}=0$ $(0 \%), \mathrm{B}=13 \quad(38,24 \%), \mathrm{C}=14 \quad(41,18 \%), \mathrm{D}=6$ $(17,65 \%), E=1(2,94 \%)$. Nilai rata-rata yang didapatkan adalah $71,90 \%$.

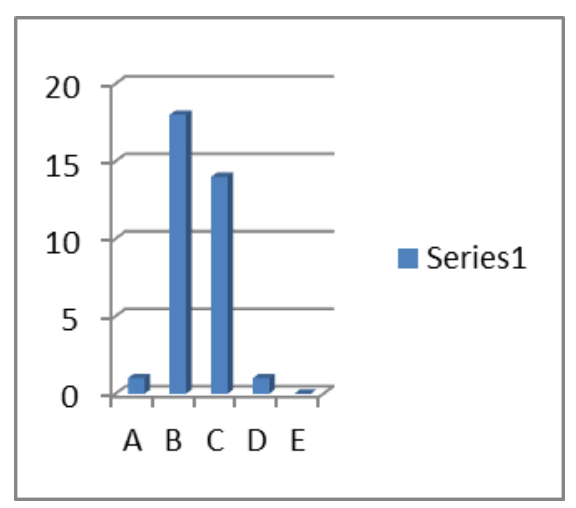

Gambar 2. Hasil Siklus 1 Tindakan 1

Sedangkan pada hasil dari siklus 1 tindakan 1, peneliti menemukan adanya kemampuan siswa dalam melaksanakan atau menguasai keterampilan bermain kasti siswa yang meningkat, di antaranya mendapatkan nilai $\mathrm{A}=1(2,94 \%)$, $\mathrm{B}=18(52,94 \%), \mathrm{C}=14(41,18 \%), \mathrm{D}=1(2,94 \%)$, $\mathrm{E}=0(0 \%)$. Nilai rata-rata yang didapatkan adalah $74,7 \%$. Berdasarkan hasil tersebut, keterampilan bermain kasti mengalami peningkatan dari rata-rata observasi awal yaitu 71,90\% naik sebanyak 2,80 menjadi 74,69\%. Dan juga dari hasil ketercapaian siswa dari 38,24\% naik sebanyak 17,64 menjadi 55,88\%.

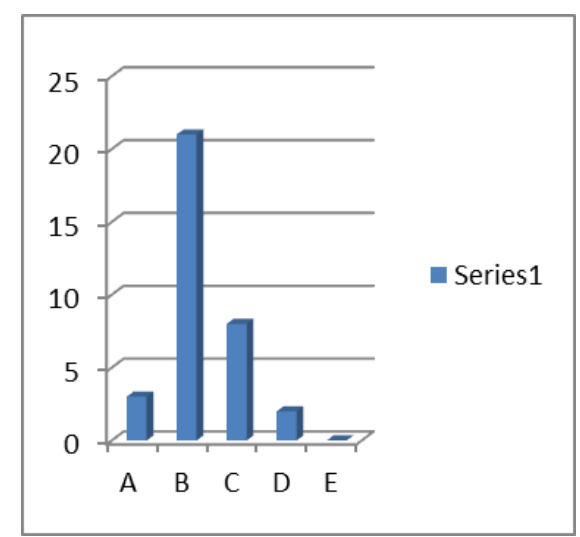

Gambar 3. Hasil Siklus 1 Tindakan 2

Dari Siklus 1 Tindakan 2 (grafik 3) peneliti menemukan hasil pembelajaran permainan kasti siswa meningkat kembali, di antaranya yang mendapatkan nilai $\mathrm{A}=3(8,82 \%)$, $\mathrm{B}=21(61,76 \%), \mathrm{C}=8(23,35 \%), \mathrm{D}=2(5,88 \%)$, $\mathrm{E}=0(0 \%)$. Nilai rata-rata yang didapatkan adalah $75,0 \%$. Berdasarkan hasil tersebut, keterampilan bermain kasti mengalami peningkatan dari rata-rata pada siklus 1 tindakan 1 sebesar $74,69 \%$ naik $0,52 \%$ menjadi $75,21 \%$.

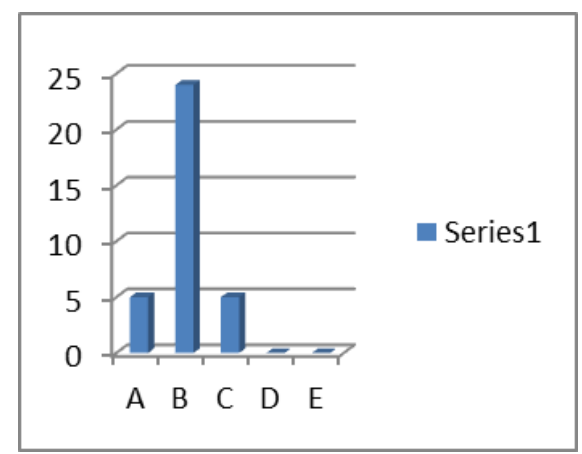

Gambar 4. Hasil Siklus 2 Tindakan 1

Pada pembelajaran siklus 2 tindakan 1 (tabel 4.4) terjadi lagi peningkatan yang mencolok, dilihat dari skor yang diperoleh adalah 
berikut: nilai $\mathrm{A}=5(14,71 \%), \mathrm{B}=24 \quad(70,59 \%)$, $\mathrm{C}=5(14,71 \%), \mathrm{D}=0(0 \%), \mathrm{E}=0(0 \%)$. Nilai ratarata yang diperoleh adalah $77,17 \%$. Hasil yang diperoleh sudah melebihi nilai KKM sekolah, yaitu 75., keterampilan bermain kasti mengalami peningkatandari rata-rata siklus 1 tindakan 2 yaitu 75,21 \% naik sebesar 1,96 menjadi $77,17 \%$.

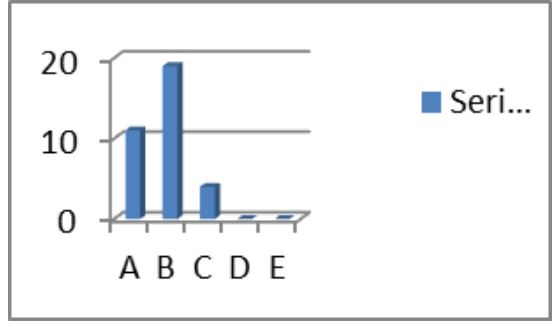

Gambar 5. Hasil Siklus 2 Tindakan 2

Dan pada pertemuan terkahir, yaitu pada siklus 2 Tindakan 2 (grafik 5) keterampilan siswa dalam bermain kasti nilai sebagai berikut: $\mathrm{A}=11 \quad(32,34 \%), \quad \mathrm{B}=19 \quad(55,88 \%), \quad \mathrm{C}=4$ $(11,76 \%), D=0(0 \%), E=0(0 \%)$. Hasil Siklus 2 Tindakan 2 presentase rata-ratanya mencapai $79,46 \%$. Berdasarkan data tersebut keterampilan bermain kasti mengalami peningkatan dan sudah melebihi nilai KKM sekolah yaitu 75 .

Secara keseluruhan, hasil penelitian dari setiap tindakan keterampilan bermain kasti, digambarkan dalam grafik berikut:

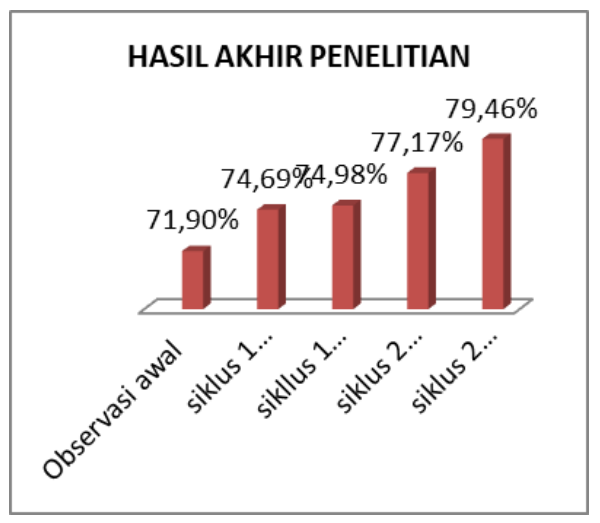

Gambar 6. Hasil Akhir Penelitian
Berdasarkan data hasil analisis diatas adapun hal-hal yang menyebabkan penelitian yang menerapkan model pendidikan gerak pada siswa kelas IV E SDN 044 Cicadas Awigombong, bahwa keterampilan siswa dalam pembelajaran kasti meningkat dengan hasil penelitian yang sudah dilakukan. Siswa mengamati gerakan yang di demonstrasikan oleh peneliti dan mengamati apa yang dilakukan oleh teman didalam proses pembelajaran Siswa mampu melakukan berbagai gerakan.

Siswa mampu bekerjasama dalam kelompok masing-masing sehingga dapat memahami dan menyelesaikan tugas yang diberikan. Dengan melakukan kerjasama kelompok dapat meningkatkan kemampuan hubungan sosial (Santyasa, 2007; Hartanto, 2014). Rasa percaya diri siswa mendorong keinginan siswa untuk melaksanakan tugas gerak yang diberikan oleh peneliti sehingga tanpa sadar siswa mampu melakukan gerakan-gerakan yang tidak biasa dia lakukan. Seperti yang di jelaskan oleh (Trianto, 2007; Mustagfiri, 2013). Dengan percaya diri yang tinggi siswa lebih berani dan tidak ragu-ragu dalam melakukan tugas gerak yang diberikan oleh peneliti. Siswa sudah melakukan dengan semangat dan percaya diri.

Siswa menjadi lebih aktif dalam mengikuti proses pembelajaran dalam melakukan interaksi dengan teman dan kelompoknya sehingga pembelajaran lebih efektif dan tidak satu arah. (Hamalik, 2008; Abdul, dkk, 2013) mengungkapkan siswa juga lebih senang belajar bila mereka dapat berperan aktif dalam upaya mencapai tujuan pembelajaran. Berdasarkan teori-teori pendukung hasil penelitian yang dipaparkan di atas dapat disimpulkan bahwa aktivitas dan hasil belajar keterampilan bermain 
kasti meningkat melalui penerapan model pendidian gerak pada siswa kelas IV E SDN 044 Cicadas awigombong.

\section{KESIMPULAN}

Model pendidikan gerak dapat diaplikasikan pada pembelajaran permainan kasti dengan memperhatikan aspek-aspek fundamental dan karakteristik dari setiap jenis permainan. Sehingga mendorong anak untuk bergerak sesuai dengan kemampuan gerak mereka dan aktif bereksplorasi.

\section{DAFTAR PUSTAKA}

Gustafianuus Abe. (2013). Meningkatkan Keterampilan Melempar dalam Bermain Kasti melalui Penerapan Bola Modifikasi pada Siswa Kelas V SDN banyusari. E-Journal Tadulako Physical Education, Health And Recreation, 1, 1-10.

Hamalik, Oemar.(2008). Kurikulum dan Pembelajaran. Jakarta: PT Bumi Aksara

Mahendra. (2017). Model Pendidikan Gerak. Bandung: FPOK-UPI

Nuryadi, dkk (2018). Hubungan Kebugaran Jasmani dengan Kemampuan Konsentrasi dan Respon Kortisol. Jurnal Pendidikan Jasmani Dan Olahraga . Vol 3 (2) (2018) 122-128. DOI : 10.17509/ jpjo.v3i2.12578

Oslin, J. L., Mitchell, S. A., \& Griffin, L. L. (1998). The Game Performance Assessment Instrument (GPAI): Development and Preliminary Validation. Journal of Teaching in Physical Education, 17(2), 231-243. https://doi.org/10.1123/ jtpe.17.2.231

Rustiana, E. R. (2013). Upaya Peningkatan Kecerdasan Emosi Siswa Sekolah Dasar Melalui Pendidikan Jasmani Harmoni. Jurnal Ilmiah Pendidikan, 5(1), 139-149. https://doi.org/10.1007/ BF02103626

Sapitri, U. E., Kurniawan, Y., \& Sulistri, E. (2016). Penerapan Model Discovery Learning Untuk Meningkatkan Ket- erampilan Berpikir Kritis Siswa Kelas X Pada Materi Kalor. JIPF (Jurnal Ilmu Pendidikan Fisika), 1(2), 64-66. https:// doi.org/10.26737/jipf.v1i2.66Sucipto. (2014). Pembelajaran Pencak Silat.

Santyasa, I Wayan dan Sukadi. (2007). ModelModel Pembelajaran Inovatif. Singaraja.

Scheuer, L. J., \& Mitchell, D. (2003). Does physical activity influence academic performance. The New PE and Sport Dimension, 12.

Stephani, M.R. (2017). Stimulasi Kemampuan Berpikir Kritis Melalui Pembelajaran Berbasis Masalah Pada Pendidikan Jasmani. Jurnal Pendidikan Jasmani Dan Olahraga, 2(1), 16-27. https:// doi.org/10.17509/jpjo.v2i1.6397

Trianto. (2007). Model-Model Pembelajaran Inovatif. Jakarta: Prestasi Pustaka Publisher. 